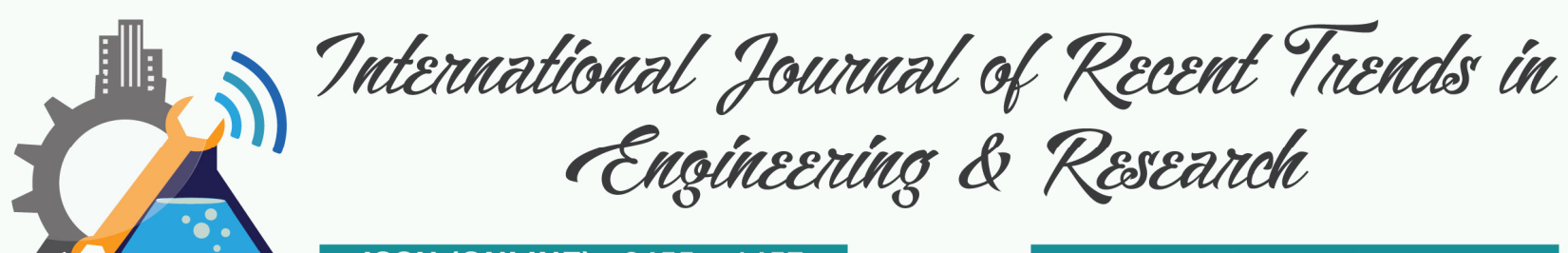

\title{
Association Rules Analysis on FP-Growth Method in Predicting Sales
}

\author{
Supiyandi ${ }^{1}$, Mochammad Iswan Perangin-angin ${ }^{2}$, Andre Hasudungan Lubis ${ }^{3}$, Ali Ikhwan ${ }^{4}$, Mesran $^{5}$, \\ Andysah Putera Utama Siahaan ${ }^{6}$ \\ ${ }^{1,2,6}$ Faculty of Computer Science, Universitas Pembangunan Panca Budi, Medan, Indonesia \\ ${ }^{3}$ Faculty of Engineering, Universitas Medan Area, Medan, Indonesia \\ ${ }^{4}$ Faculty of Science and Technology, Universitas Islam Negeri Sumatera Utara, Medan, Indonesia \\ ${ }^{5}$ Department of Informatics, STMIK Budi Darma, Medan, Indonesia \\ ${ }^{4,6}$ School of Computer and Communication Engineering, Universiti Malaysia Perlis, Pauh, Malaysia
}

\begin{abstract}
Sales transaction data on a company will continue to increase day by day. Large amounts of data can be problematic for a company if it is not managed properly. Data mining is a field of science that unifies techniques from machine learning, pattern processing, statistics, databases, and visualization to handle the problem of retrieving information from large databases. The relationship sought in data mining can be a relationship between two or more in one dimension. The algorithm included in association rules in data mining is the Frequent Pattern Growth (FP-Growth) algorithm is one of the alternatives that can be used to determine the most frequent itemset in a data set.
\end{abstract}

Keywords:Data Mining, Association Rules, FP-Growth.

\section{INTRODUCTION}

Promotional items are a strategy on marketing economics to market a product or even service to increase a company's sales quantity [11][12]. Purchasing and selling is an activity that affects the amount of stock of goods. Then the information generated will help managers in deciding a promotional activity for the introduction of an item to the public.

Data mining is a field of science that unifies techniques from machine learning, pattern processing, statistics, databases, and visualization to handle the problem of retrieving information from large databases [2]. The relationship sought in data mining can be a relationship between two or more in one dimension. For example, in product dimension, there is the relation of purchasing a product with other product. Also, the relationship can also be seen between two or more attributes and two or more objects.

Data mining can analyze large data into information in the form of patterns that have to mean for decision supporters. However, the number of existing data is not always followed by the knowledge that can be generated by the data that many, so in the end, the data only become a less useful. Data mining is the process of searching for patterns of interest and hidden pattern of a large data set stored in a database, such as data warehouse and other data storage [1][3][4].

One important factor in data mining is the existence of rules to find a high-frequency pattern among the itemsets. It is called the Association Rule. FP-Growth is an algorithm included in association rules. Frequent Pattern Growth (FP-Growth) is one of the alternative algorithms that can be used to determine the most common set of data in a dataset. The algorithm searches for the Association Rule by using the value parameters of support and confidence. 


\subsection{Data Mining}

\section{THEORIES}

Data mining is a process that uses statistical, mathematical, artificial intelligence, and machine learning techniques to extract and identify useful information and as the extraction of useful information and related knowledge from large databases. Several different approaches are classified as information/knowledge seeking techniques in KDD [5][7]. There are quantitative approaches, such as probabilistic approaches such as inductive logic, pattern search, and decision tree analysis. Other approaches include deviation, trend analysis, genetic algorithms, artificial neural networks, and mixed approaches of two or more of several approaches. There are several elements in information search techniques/knowledge in KDD are:

- Working large amounts of data

- Requires efficiency related to the volume of data

- Priority determination/accuracy

- Requires high-level language usage

- Use some form of automatic learning

- Produce interesting things

A company needs business intelligence to develop business processes, monitor time, quality cost, and control about the improvement of a company's quality. In this definition presented that business intelligence is the process of converting data into information. From the collection of existing information will be taken into a pattern of knowledge [6][8]. The purpose of business intelligence is to convert very much data into business value through an analytical report. Data Mining is a series of processes to explore the added value of a data set that produces knowledge that has not been known manually.

\subsection{Data Mining Step}

Data mining is part of Knowledge Discovery Database (KDD). Data mining is not as a stand-alone technology. It is an important step in the KDD mainly relating to the extraction and calculation of the patterns of the data being sliced [9][10]. Some stages in the process of data mining:

- A Precise statement of the problem. For example, the decision if the bank wants to know whether a customer has the potential to have bad credit, or identify a customer whether to move to the competitor of our business and so forth. After finding the business questions that need to be answered by data mining, then determine the type of task to answer the business questions. The basic tasks that form the basis of data mining algorithms are classification, regression, segmentation, association and sequence analysis.

- Initial Exploration. It is to prepare data to be a source for data mining including data cleaning to learn the pattern.

- After finding the definition of the problem, the next step is to look for data that supports the problem definition. Determine the portion of data used to training data mining based on data mining algorithms that have been made. After the data preparation is completed, the next step is to provide some data into the data mining algorithm.

- Model building and validation. Validate whether data mining provides accurate predictions. After the data training is completed, the data mining needs to be "tested" or validated accurately to the data testing.

- Deployment. This stage selects the right application against data mining to make predictions. 


\section{RESULTS AND DISCUSSION}

In this study, the author uses FP-Growth method that will be utilized in solving the problem of fruit sales analysis which will be used to know a promotion strategy itemset in improving the quality of sales. In this chapter will discuss the analysis of sales data that affect the sales of fruit by using frequent pattern growth.

Table 1. Sales transaction data

\begin{tabular}{|c|c|c|c|c|}
\hline No. & Fruit & Date & Week & Day \\
\hline 1 & Grape & 1-Mar-17 & I & Wednesday \\
\hline 2 & Apple & 1-Mar-17 & I & Wednesday \\
\hline 3 & Kiwi & 1-Mar-17 & I & Wednesday \\
\hline 4 & Mango & 1-Mar-17 & I & Wednesday \\
\hline 5 & Dragonfruit & 1-Mar-17 & I & Wednesday \\
\hline 6 & Mango & 3-Mar-17 & I & Friday \\
\hline 7 & Orange & 3-Mar-17 & I & Friday \\
\hline 8 & Lemon & 3-Mar-17 & I & Friday \\
\hline 9 & Pear & 3-Mar-17 & I & Friday \\
\hline 10 & Kiwi & 3-Mar-17 & I & Friday \\
\hline 11 & Dragonfruit & 5-Mar-17 & I & Sunday \\
\hline 12 & Sugar Palm Fruit & 5-Mar-17 & I & Sunday \\
\hline 13 & Watermelon & 5-Mar-17 & I & Sunday \\
\hline 14 & Apple & 5-Mar-17 & I & Sunday \\
\hline 15 & Banana & 5-Mar-17 & I & Sunday \\
\hline 16 & Melon & 6-Mar-17 & II & Monday \\
\hline 17 & Snakefruit & 6-Mar-17 & II & Monday \\
\hline 18 & Papaya & 6-Mar-17 & II & Monday \\
\hline 19 & Pear & 6-Mar-17 & II & Monday \\
\hline 20 & Pear & 6-Mar-17 & II & Monday \\
\hline 21 & Banana & 9-Mar-17 & II & Thursday \\
\hline 22 & Dragonfruit & 9-Mar-17 & II & Thursday \\
\hline 23 & Litchi & 9-Mar-17 & II & Thursday \\
\hline 24 & Dates & 9-Mar-17 & II & Thursday \\
\hline 25 & Watermelon & 9-Mar-17 & II & Thursday \\
\hline 26 & Pear & 9-Mar-17 & II & Thursday \\
\hline 27 & Apple & 9-Mar-17 & II & Thursday \\
\hline 28 & Orange & 9-Mar-17 & II & Thursday \\
\hline 29 & Pineapple & 11-Mar-17 & III & Saturday \\
\hline 30 & Melon & 11-Mar-17 & III & Saturday \\
\hline 32 & Banana & 11-Mar-17 & III & Saturday \\
\hline
\end{tabular}




\begin{tabular}{|c|c|c|c|c|}
\hline 33 & Banana & 11-Mar-17 & III & Saturday \\
\hline 34 & Pear & 11-Mar-17 & III & Saturday \\
\hline 35 & Tomato & 11-Mar-17 & III & Saturday \\
\hline 36 & Pumpkin & 12-Mar-17 & III & Sunday \\
\hline 37 & Banana & 12-Mar-17 & III & Sunday \\
\hline 38 & Blueberry & 12-Mar-17 & III & Sunday \\
\hline 39 & Orange & 12-Mar-17 & III & Sunday \\
\hline 40 & Avocado & 12-Mar-17 & III & Sunday \\
\hline 41 & Lemon & 12-Mar-17 & III & Sunday \\
\hline 42 & Apple & 14-Mar-17 & III & Tuesday \\
\hline 43 & Pear & 14-Mar-17 & III & Tuesday \\
\hline 44 & Mango & 14-Mar-17 & III & Tuesday \\
\hline 45 & Orange & 14-Mar-17 & III & Tuesday \\
\hline 46 & Lemon & 14-Mar-17 & III & Tuesday \\
\hline 47 & Banana & 14-Mar-17 & III & Tuesday \\
\hline 48 & Apple & 14-Mar-17 & III & Tuesday \\
\hline 49 & Mango & 16-Mar-17 & III & Thursday \\
\hline 50 & Orange & 16-Mar-17 & III & Thursday \\
\hline 51 & Watermelon & 16-Mar-17 & III & Thursday \\
\hline 52 & Pineapple & 16-Mar-17 & III & Thursday \\
\hline 53 & Papaya & 16-Mar-17 & III & Thursday \\
\hline 54 & Snakefruit & 16-Mar-17 & III & Thursday \\
\hline 55 & Mango & 16-Mar-17 & III & Thursday \\
\hline 56 & Grape & 16-Mar-17 & III & Thursday \\
\hline 57 & Litchi & 16-Mar-17 & III & Thursday \\
\hline 58 & Pear & 17-Mar-17 & III & Friday \\
\hline 59 & Tomato & 17-Mar-17 & III & Friday \\
\hline 60 & Banana & 17-Mar-17 & III & Friday \\
\hline 61 & Lemon & 17-Mar-17 & III & Friday \\
\hline 62 & Apple & 17-Mar-17 & III & Friday \\
\hline 63 & Orange & 17-Mar-17 & III & Friday \\
\hline 64 & Kiwi & 17-Mar-17 & III & Friday \\
\hline 65 & Dragonfruit & 17-Mar-17 & III & Friday \\
\hline 66 & Melon & 17-Mar-17 & III & Friday \\
\hline 67 & Pear & 17-Mar-17 & III & Friday \\
\hline 68 & Melon & 20-Mar-17 & IV & Monday \\
\hline 69 & Sugar Palm Fruit & 20-Mar-17 & IV & Monday \\
\hline 70 & Lemon & 20-Mar-17 & IV & Monday \\
\hline 71 & Mango & 20-Mar-17 & IV & Monday \\
\hline 72 & Pear & 20-Mar-17 & IV & Monday \\
\hline 73 & Dates & 20-Mar-17 & IV & Monday \\
\hline
\end{tabular}




\begin{tabular}{|c|c|c|c|c|}
\hline 74 & Orange & 20-Mar-17 & IV & Monday \\
\hline 75 & Blueberry & 20-Mar-17 & IV & Monday \\
\hline 76 & Tomato & 20-Mar-17 & IV & Monday \\
\hline 77 & Pumpkin & 20-Mar-17 & IV & Monday \\
\hline 78 & Lemon & 22-Mar-17 & IV & Wednesday \\
\hline 79 & Pear & 22-Mar-17 & IV & Wednesday \\
\hline 80 & Dragonfruit & 22-Mar-17 & IV & Wednesday \\
\hline 81 & Pear & 22-Mar-17 & IV & Wednesday \\
\hline 82 & Papaya & 22-Mar-17 & IV & Wednesday \\
\hline 83 & Melon & 22-Mar-17 & IV & Wednesday \\
\hline 84 & Dates & 22-Mar-17 & IV & Wednesday \\
\hline 85 & Orange & 22-Mar-17 & IV & Wednesday \\
\hline 86 & Apple & 22-Mar-17 & IV & Wednesday \\
\hline 87 & Mango & 26-Mar-17 & IV & Sunday \\
\hline 88 & Banana & 26-Mar-17 & IV & Sunday \\
\hline 89 & Melon & 26-Mar-17 & IV & Sunday \\
\hline 90 & Lemon & 26-Mar-17 & IV & Sunday \\
\hline 91 & Blueberry & 26-Mar-17 & IV & Sunday \\
\hline 92 & Orange & 26-Mar-17 & IV & Sunday \\
\hline 93 & Banana & 26-Mar-17 & IV & Sunday \\
\hline 94 & Pineapple & 26-Mar-17 & IV & Sunday \\
\hline 95 & Sugar Palm Fruit & 26-Mar-17 & IV & Sunday \\
\hline 96 & Lemon & 26-Mar-17 & IV & Sunday \\
\hline 97 & Lemon & 26-Mar-17 & IV & Sunday \\
\hline 98 & Kiwi & 28-Mar-17 & $\mathrm{V}$ & Tuesday \\
\hline 99 & Grape & 28-Mar-17 & $\mathrm{V}$ & Tuesday \\
\hline 100 & Litchi & 28-Mar-17 & $\mathrm{V}$ & Tuesday \\
\hline 101 & Pear & 28-Mar-17 & $\mathrm{V}$ & Tuesday \\
\hline 102 & Papaya & 28-Mar-17 & $\mathrm{V}$ & Tuesday \\
\hline 103 & Dragonfruit & 28-Mar-17 & $\mathrm{V}$ & Tuesday \\
\hline 104 & Orange & 28-Mar-17 & $\mathrm{V}$ & Tuesday \\
\hline 105 & Pear & 31-Mar-17 & $\mathrm{V}$ & Friday \\
\hline 106 & Lemon & 31-Mar-17 & $\mathrm{V}$ & Friday \\
\hline 107 & Tomato & 31-Mar-17 & $\mathrm{V}$ & Friday \\
\hline 108 & Mango & 31-Mar-17 & $\mathrm{V}$ & Friday \\
\hline 109 & Pear & 31-Mar-17 & $\mathrm{V}$ & Friday \\
\hline 110 & Avocado & 31-Mar-17 & $\mathrm{V}$ & Friday \\
\hline 111 & Blueberry & 31-Mar-17 & $\mathrm{V}$ & Friday \\
\hline 112 & Kiwi & 31-Mar-17 & $\mathrm{V}$ & Friday \\
\hline 113 & Dragonfruit & 31-Mar-17 & $\mathrm{V}$ & Friday \\
\hline 114 & Banana & 31-Mar-17 & $\mathrm{V}$ & Friday \\
\hline
\end{tabular}


Table 2 shows an example of some types of fruit taken for experimental material on FP-Growth method calculations.

Table 2. Range per week

\begin{tabular}{cccccc} 
No. & Fruit & Initial & Transaction & Range & Remark \\
\hline 1 & Snakefruit & SF & 2 & 0,4 & II, III \\
2 & Grape & GR & 3 & 0,6 & I, III, V \\
3 & Apple & AP & 7 & 0,8 & I, II, III, IV \\
4 & Banna & BN & 10 & 1 & I, II, III, IV, V \\
5 & Kiwi & KW & 5 & 0,6 & I, III, V \\
6 & Mango & MG & 8 & 0,8 & I, III, IV, V \\
7 & Papaya & PY & 4 & 0,8 & II, III, IV, V \\
8 & Melon & ML & 6 & 0,6 & II, III, V \\
9 & Orange & OR & 11 & 1 & I, II, III, IV, V \\
10 & Pear & PR & 14 & 1 & I, II, III, IV, V \\
\hline
\end{tabular}

The sample data is based on one-month sales data. The following table will display sample transaction data within one month.

Table 3. Sales rate

\begin{tabular}{c|cccccccccc} 
Week & $\mathbf{1}$ & $\mathbf{2}$ & $\mathbf{3}$ & $\mathbf{4}$ & $\mathbf{5}$ & $\mathbf{6}$ & $\mathbf{7}$ & $\mathbf{8}$ & $\mathbf{9}$ & $\mathbf{1 0}$ \\
\hline I & & GR & AP & BN & KW & MG & & & OR & PR \\
II & SL & & AP & BN & & & PY & ML & OR & PR \\
II & SL & GR & AP & BN & KW & MG & PY & ML & OR & PR \\
IV & & & AP & BN & & MG & PY & ML & OR & PR \\
V & & GR & & BN & KW & MG & PY & & OR & PR
\end{tabular}

The sample transaction data in the previous table is the sample data to be processed using FP-Growth. The frequency of occurrence of each item from the transaction data can be seen in the following table.

Table 4. Sales item occurrence

\begin{tabular}{ccccc} 
No. & Initial & Frequency & $\begin{array}{c}\text { Support } \\
\text { Frequency }\end{array}$ & Support \\
\hline 1 & SF & 2 & $2 / 5$ & $40 \%$ \\
2 & GR & 3 & $3 / 5$ & $60 \%$ \\
3 & AP & 4 & $4 / 5$ & $80 \%$ \\
4 & BN & 5 & $5 / 5$ & $100 \%$ \\
5 & KW & 3 & $3 / 5$ & $60 \%$ \\
6 & MG & 4 & $4 / 5$ & $80 \%$ \\
7 & PY & 4 & $4 / 5$ & $80 \%$ \\
8 & ML & 3 & $3 / 5$ & $60 \%$ \\
9 & OR & 5 & $5 / 5$ & $100 \%$ \\
10 & PR & 5 & $5 / 5$ & $100 \%$ \\
\hline
\end{tabular}


Table 4 describes the results of the frequency of occurrence of items of sale through transactions each week. This result will determine support. This study takes the value of support count $\xi=75 \%$ and the value of support count will affect the items that will be analyzed phases of making FP-Tree. It determines the highest support value and that meets the $75 \%$ support account. It is the value that a company's agency needs in looking at the average percentage of transactions. The frequency of transactions in a day divided by the number of attributes to find the percentage value of support. It will find an item that meets the frequency, then the item to be used for next is an item that meets the frequency of $\geq 75 \%$ as shown in table 5 .

Table 5. Support and frequency

\begin{tabular}{ccccc} 
No. & Initial & Frequency & $\begin{array}{c}\text { Support } \\
\text { Frequency }\end{array}$ & Support \\
\hline 1 & AP & 4 & $4 / 5$ & $80 \%$ \\
2 & BN & 5 & $5 / 5$ & $100 \%$ \\
3 & MG & 4 & $4 / 5$ & $80 \%$ \\
4 & PY & 4 & $4 / 5$ & $80 \%$ \\
5 & OR & 5 & $5 / 5$ & $100 \%$ \\
6 & PR & 5 & $5 / 5$ & $100 \%$ \\
\hline
\end{tabular}

The data will be scanned based on the data frequency occurrence table. Other items that do not meet the frequency of occurrence of support account that is SF with support value 40\%, GR with support value $60 \%, \mathrm{KW}$ with support value $60 \%$ and ML with support value $60 \%$ each does not meet minimum value support $75 \%$ are not scanned. After the process of scanning the data between the frequency table of the emergence of data and the frequency table emergence of support accounts, then the process of data mining can be seen in the following table.

Table 6. Support account occurrence

\begin{tabular}{|c|c|}
\hline Week & Transaction \\
\hline I & AP, BN, MG, OR, PR \\
\hline II & AP, BN, PY, OR, PR \\
\hline III & AP, BN, MG, PY, OR, PR \\
\hline IV & AP, BN, MG, PY, OR, PR \\
\hline V & BN, MG, PY, OR, PR \\
\hline
\end{tabular}

IV. CONCLUSION

Based on testing done in the previous stage, it can be concluded that the data mining can be implemented by using a sales database to find trends in pattern itemsets combination so it can be used as valuable information in making decisions to prepare the stock of goods and marketing strategies required later. The application of the FP-Growth algorithm to marketing technique has a very efficient ease and can accelerate the process of formation of the trend of sales item combination pattern. It can be done by promoting items that do not enter the expected confidence.

\section{REFERENCES}

I. Fadlina, L. T. Sianturi, A. Karim, and Mesran, "Best Student Selection Using Extended Promethee II Method," International Journal of Recent Trends in Engineering \& Research, vol. 3, pp. 21-29, 2017.

II. W. Fitriani, "Comparison Between WEKA and Salford System in Data Mining Software," International Journal 
of Mobile Computing \& Application, vol. 3, pp. 01-04, 2016.

III. H. A. Hasibuan, and R. B. Purba, "Productivity Assessment (Performance, Motivation, and Job Training) using Profile Matching," International Journal of Economics and Management Studies, vol. 3, pp. 73-77, 2016.

IV. Khairul, and M. Simaremare, "Decision Support System in Selecting the Appropriate Laptop Using Simple Additive Weighting," International Journal of Recent Trends in Engineering \& Research, vol. 2, pp. 215-222, 2016.

V. Mesran, K. Tampubolon, R. D. Sianturi, F. T. Waruwu, and A. P. U. Siahaan, "Determination of Education Scholarship Recipients Using Preference Selection Index," International Journal of Scientific Research in Science and Technology, vol. 3, pp. 230-234, 2017.

VI. M. I. Perangin-angin, W. Fitriani, and N. Mayasari, "Tuition Reduction Determination Using Fuzzy Tsukamoto," International Journal of Engineering Science Invention, vol. 5, pp. 68-72, 2016.

VII. A. P. U. Siahaan, "Fuzzification of College Adviser Proficiency Based on Specific Knowledge," International Journal of Advanced Research in Computer Science and Software Engineering, vol. 6, pp. 164-168, 2016.

VIII. Z. Tharo, "Profile Matching in Solving Rank Problem," IOSR J ournal of Electronics and Communication Engineering, vol. 11, pp. 73-76, 2016.

IX. L. Marlina, and Muslim, "Data Mining Classification Comparison (Naïve Bayes and C4.5 Algorithms)," Inte rnational Journal of Engineering Trends and Technology, vol. 38, pp. 380-383, 2016.

X. I. Sumartono, D. Arisandi, and Mesran, "Expert System of Catfish Disease Determinant Using Certainty Factor Method," International Journal of Recent Trends in Engineering \& Research, vol. 3, pp. 202-209, 2017.

XI. R. B. Purba, "The Analysis of Good Profitability Governance Using Markov Chain inSmall Business," International Journal for Innovative Research in Multidisciplinary Field, vol. 3, pp. 01-06, 2017. 